\title{
Research on Accounting Internal Control in Listed Company under ERP Environment
}

\author{
Xin Cheng ${ }^{1, a}$, Yinxing $\mathrm{Li}^{1, \mathrm{~b}}$ \\ ${ }^{1}$ School of Economic Management, Beihua University, 132013, Jilin City, China \\ ${ }^{a}$ Xi-cheng007@126.com, ${ }^{b}$ nyjjgl@126.com
}

Keywords: ERP environment; Listed company; Internal accounting control

Abstract. With the enterprise network management and accounting information construction applying deeply, as well as domestic enterprise risk management system construction work step by step. It is urgent hope in accounting theory circles to study under the environment of ERP listed company accounting internal control framework system problem. In this paper, the new theory was proposed to guide the enterprises from the traditional management to information management practice.

\section{Introduction}

ERP system is the core of business operations, process management and quantitative management, through system integration to simplify the various departments and between the various aspects of the work of most of the information is passed into one unified platform up, eliminating the random processes and information processing, and different concepts of ambiguity. Since the line ERP system, Sinopec, has been around the business development strategy, information systems as the basis, to achieve a standardized basis for data integration in the country, to share information across the company, and automate information flow and processing of the progressive realization of BOM data linkage to achieve integrated management of financial data and business data, to achieve synergy internal supply chain planning, and comprehensively improve the quality of management, the implementation of a comprehensive budget management and performance management to provide effective decision support for business decisions and management. For sure that many aspects of the business goals, the implementation of national laws and regulations, the accounting information quality assurance, as well as property and materials to carry out security and auditing work has a very important role. Thus, the establishment of internal accounting control system in the ERP environment ERP project implementation indispensable part. Accounting internal control is an important part of the realization of the modern enterprise management, but also the production and operation activities which are essential for the smooth progress.

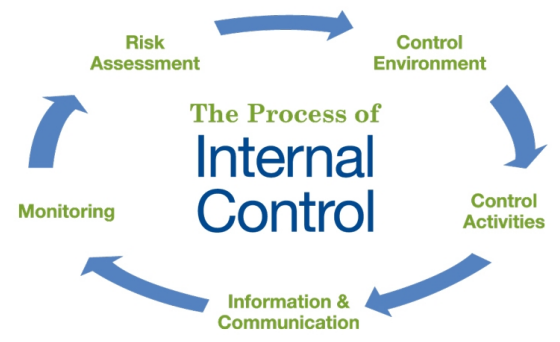

Fig. 1 The process of internal control

\section{The concept of internal accounting controls}

Internal accounting controls essentially directly to the business capital movement as the role of the object, which provides guidance and support functions for the rational and effective liquidity; the premise flows both economic activities of funds can be achieved, but also the enterprise all economic activities the ultimate realization of the form it runs through the entire process and all aspects of 
economic activity, which also makes internal accounting controls throughout the enterprise internal control system and all aspects of the whole process, the core of internal control.

Accounting Internal Control object is the movement of funds, accounting internal control relevant decision-making body is the other sector accounting department and accounting information for controlling the movement of funds, accounting organization system of internal control is based on the accounting department as the center of each department to infiltrate the enterprise ERP system. Mainly refers to the internal control of the company for accounting, accounting information transmission, the financial reporting process, such as the establishment of financial disclosure information. Its fundamental purpose is to ensure that accounting information is true, reliable and complete. For listed companies, these things are important, but also the corporate governance bodies and regulatory agencies to focus on content.

Internal accounting controls by the control environment, accounting system and control program thereof. Wherein the control environment is the overall attitude of the authorities of internal control and its importance, awareness and action; accounting system is a financial information system for confirmation, recording, measuring and reporting on economic and business matters. By accounting system for all economic and business transactions will eventually be reflected in the financial statements. Internal control system is a system that its accounting system is an important part of the organization of internal accounting controls.

\section{Target Accounting Internal Control}

Accounting internal control system is to ensure that accounting data authenticity, reliability and protection of property and materials for the purpose of use and accounting services and other related aspects of business management methods, measures and procedures, and be standardized, systematic, so that with an effective control mechanism established companies only strict accounting and internal control system implemented in order to ensure true and reliable accounting data business, property will not be lost. Events today's society due to economic development, the development of cultural diversity, people's thinking has undergone tremendous change, also enhanced the allure of material wrongdoing is also a substantial increase in forgery and fabricating false financial and accounting reports of repeated have occurred, the accounting information distortion problem becomes a problem of public concern, it not only affects the normal production and operation lasting manner, but also hinder the macroeconomic development. Some units of the absence of a sound and effective, the lack of scientific and coherence of internal control, degree, resulting in some of the accounting system out of nowhere, or so that the accounting information in the transfer process due to a problem with disjointed and / Some units because of the internal control system was the effective implementation of such rules and regulations and not non-existent, there are chapters that do not follow, resulting in distortion of accounting information. Visible to strengthen the accounting internal control system is to solve the distortion of accounting information to ensure the normal operation of the objective requirements of the national economy.

\section{Accounting Internal Control Role}

Accounting Internal Control system has checks and cooperate with incentives and facilitating role. Rational use of internal accounting controls, will help improve the credibility and reliability of accounting and other information; and promoting property management and effective use of resources; help reduce unnecessary support, improve profitability, to avoid accidents risk; help ensure complete authorization and legal responsibilities; conducive to the prevention and reduction of errors and fraud.

(1) Strengthen and improve internal accounting controls will help to ensure the effective implementation of the relevant national legal system, to ensure that the internal operating decisions and regulations can be implemented correctly. The implementation of national policies and financial regulations, is a prerequisite for legitimate business enterprises. Improve and perfect the internal accounting controls within the enterprise can be various functional departments, positions, personnel 
and various aspects of effective supervision and control of the legality of economic activity, compliance of strict censorship and control, to identify problems and take effective measures to be corrected to ensure that the implementation of in-house corporate regulations and the relevant national legal system.

(2) Strengthen and improve internal accounting controls help to ensure the reliability and authenticity of accounting information, and thus to meet the market needs of economic development. True and reliable accounting information is the basis for all aspects of enterprise scientific decision-making. Through the establishment of a rigorous, standardized accounting internal control, will be able to largely prevent errors and fraud, accounting supervision and restraint behavior of enterprises, to ensure a variety of information recording, classifying, collecting and other procedures could truly reflect the production and operation activities the actual situation, to discover and correct various errors, and thus to ensure the authenticity and reliability of various information, correctness of the decision support information, safeguard the socialist market order.

(3) Strengthen and improve internal accounting controls in favor of an effective guard against operational risks and achieve business objectives. Enterprise survival and development to achieve the goal, it is necessary for all kinds of effective risk prevention and control, accounting internal control as the central link in enterprise management, enterprise risk prevention is the most effective as a means by which an effective enterprise risk assessment, continue to strengthen the business risk control weaknesses, the risks companies nipped in the bud. At the same time sound and effective internal accounting controls to enable businesses of all sectors of production, marketing, finance and other closely, through accounting and use of accounting information on enterprise production and business activities of the command, regulate, control, thus ensuring maximization of enterprise .

(4) Strengthen and improve internal accounting controls to avoid the occurrence of corporate corruption. Accounting has two basic functions of accounting and oversight, oversight functions of accounting means that, before the occurrence of the economic matters, economic matters and economic matters in the future occurs, the use of budget means, inspection, assessment, analysis, the unit of currency and fingers the authenticity of its economic activity, integrity, compliance and effectiveness of the guidance and control. Accounting Internal Control as an important part of enterprise management system, we can establish an effective monitoring mechanism for all levels of the main people in charge of decision-making, business and individuals to monitor the actions, which can prevent the occurrence of corporate corruption.

Taking a company as a case study, combined with elements of the internal control framework, at insights ERP status of internal accounting controls, based on the current ERP environment for the presence of internal control problems, we put forward how to establish and improve the company accounting internal control system, strengthen the basic work principles and recommendations, and establish an internal control system should insist, however, it should be noted that, under the ERP environmental accounting internal control is not strengthened in the short term can be done, nor rely on their own the effort can achieve. At the same time, enterprise information systems are constantly upgrading and improvement of internal accounting control system has also been adapted to the new circumstances.

\section{Conclusions}

With the development of society and continue to improve gradually deepened. Today, with the accelerated process of information of Chinese enterprises gradually to forward the information-oriented network, which uses network management accounting internal control mode, Research ERP accounting internal control environment has cropped up. However, information technology, networking is a gradual process, in this process of internal accounting controls businesses may face alternately run traditional management and network management and appropriate internal control reference network model some advanced experience and methods. ERP implementation of a company building has been effective in the area outside the company's ERP project is in order. ERP 
implementation for the optimization of business processes, strengthen cost control, standardize business practices to enhance the management capacity of plugging loopholes in management, improve economic efficiency has a positive role in promoting, it is a necessary means to enhance competitiveness. Construction ERP success can greatly improve enterprise management, enterprise management to achieve a breakthrough, a huge benefit to the enterprise. Petrochemical industry companies to achieve sustainable and healthy development, to establish and maintain a sustained and effective internal accounting control system is one of the prerequisites. Case studies can be seen enterprises to establish internal control system, to strengthen the management and accelerate the development of great significance.

ERP environment accounting internal control system is standardized, transparent, efficient and collaborative. ERP applications can help companies headquarters and all branches and levels of dynamic, real-time information exchange, in order to achieve vertical integration of the entire enterprise; achieve integrated business management functions on the enterprise production, supply, marketing, human, financial , material and other production and business factors and aspects of integration as an organic whole, in order to achieve horizontal integration of enterprise business functions; can help companies achieve highly integrated and unified logistics, capital flow, information flow, work flow, so that enterprises gradually virtualization, agile and advanced form of interaction. Complete information technology companies, based on their means of information and management systems based on more standardized methods, management processes more rational, more transparent information, faster customer response, each unit within the organization, operational coordination across organizations more smoothly. This article is based Construction Public Company Accounting internal control framework under the ERP environmental research, the purpose of the network is hoping the process of China's listed companies, accounting for the company's internal control serving as a reference.

\section{Corresponding Author:}

Professor Yinxing Li, School of Economic Management, Beihua University, 132013, Jilin City, China.

\section{References}

[1] Deng Chunhua. Internal Accounting Control Status and Development Suggestions. Auditing Research, 2005,3

[2] Song Jie based ERP enterprise control optimization accounting communications, 2009, (5)

[3] Cattle Yanfang .ERP accounting information systems to explore issues related to enterprise management information, 2005, (8)

[4] Zhao voyage. Implementation of ERP and several issues should be noted. China Petrochemical, $2000(3)$

[5] Liu Xin. Using the ERP system to strengthen internal controls. Business Economics, 2004, (7)

[6] Now Tang Jie, Zhao Shuangli. Construction of the network environment Enterprise Group Financial Control System. ACCOUNTING, 2004

[7] Xia Zhiqin. Enterprise Internal Control Evaluation Index System. Accounting communications (Money Edition), 2007,5 